\title{
Carnitine content of rabbit epididymal spermatozoa in organ culture
}

\author{
E. R. Casillas and Surang Chaipayungpan \\ Department of Chemistry, New Mexico State University, Las Cruces, New Mexico 88003, \\ U.S.A.
}

\begin{abstract}
Summary. Tubules of the rabbit proximal corpus epididymidis were maintained for $24 \mathrm{~h}$ in vitro. The carnitine content in cells from tubules cultured with dihydrotestosterone was greater than that in cells from tubules cultured without androgen. The effect of dihydrotestosterone was abolished by the simultaneous addition of cyproterone acetate to the medium. Culture of segments of the distal corpus for $24 \mathrm{~h}$ with dihydrotestosterone did not change the carnitine content of spermatozoa. These results support our hypothesis that the accumulation of carnitine is involved in sperm maturation.
\end{abstract}

\section{Introduction}

Carnitine is present in exceedingly high concentration in the epididymis of rats (Marquis \& Fritz, 1965a; Casillas, 1972; Brooks, Hamilton \& Mallek, 1974) and other species (Casillas, 1972). Carnitine accumulates in bovine (Casillas, 1973) and in rabbit (Casillas \& Chaipayungpan, 1979) spermatozoa as they mature in the epididymis and we have suggested that one of the functions of the organ is to supply carnitine to spermatozoa as they mature. We have also presented evidence that carnitine plays a special role in the metabolism of mature bovine and monkey spermatozoa (Casillas \& Erickson, 1975a). In addition, many others have studied the occurrence of carnitine in the male reproductive tract and its relation to the metabolism of the epididymis and spermatozoa and these studies have been recently reviewed (Brooks, 1980; Hinton \& Setchell, 1980; Carter, Stratman, Hutson \& Lardy, 1980).

Marquis \& Fritz (1965b) first demonstrated that testosterone was necessary to maintain epididymal carnitine levels in rats and Casillas \& Erickson (1975b) confirmed these results and also showed that epididymal tissue and spermatozoa lack the ability to synthesize carnitine de novo. Although Casillas (1973) noted that bovine spermatozoa from the caput epididymidis accumulate isotopically-labelled carnitine in vitro while spermatozoa from the cauda epididymidis do not, the rate of accumulation was not increased by testosterone or dihydrotestosterone. Furthermore, the optimal rate of carnitine uptake in vitro was too slow to produce significant increases in the cellular carnitine content during the relatively short incubation periods necessary to retain cellular viability. Orgebin-Crist, Danzo \& Davies (1975) have reviewed the numerous investigations that show that the development and maintenance of sperm fertilizing ability in the epididymis is regulated by androgens. Sperm maturation can be induced in isolated tubules from the proximal corpus epididymidis in vitro by addition of $5 \alpha$-androstane-3,17 $\beta$-diol (dihydrotestosterone) to the culture medium (Orgebin-Crist \& Tichenor, 1973) and this induction can be suppressed by the further addition of cyproterone acetate (Orgebin-Crist \& Jahad, 1978). We have now studied the uptake of carnitine by spermatozoa in isolated epididymal tubules in vitro. 


\section{Materials and Methods}

\section{Animals}

Adult rabbits of proven fertility and of various breeds (primarily, New Zealand White) were obtained from a local rabbit breeder: 190 animals were used. Immediately after killing the animals, the testes and epididymides were removed from the scrotum under sterile conditions and the proximal corpus epididymidis was prepared for culture.

\section{Culture methods}

Tubules were prepared for culture by a slight modification of the procedure described by Orgebin-Crist \& Jahad (1978). As much connective tissue as possible was removed without rupturing the tubule which was then placed in a $0.1 \%$ solution of collagenase for $30 \mathrm{~min}$ at $37^{\circ} \mathrm{C}$ to digest the remaining connective tissue. After enzyme treatment, the tubule was gently, but thoroughly, rinsed with culture medium and then placed in the centre of a Petri dish. The tubules were cultured in Medium 199 supplemented with 15\% calf serum, a penicillin-streptomycin mixture (100 i.u.), and $25 \mathrm{mM}$-L-carnitine for $24 \mathrm{~h}$ at $31^{\circ} \mathrm{C}$ in an incubator that was continuously flushed with air containing $5 \% \mathrm{CO}_{2}$. Dihydrotestosterone and cyproterone acetate were dissolved in a small volume of ethanol and added to the appropriate culture medium with the final ethanol concentration less than $1 \%$. Equal concentrations of ethanol were added to the appropriate control dishes.

\section{Carnitine analysis of spermatozoa}

After culture, the tubules were removed from the medium, lacerated in a small volume of buffered salt solution containing $20 \mathrm{~mm}-\mathrm{NaH}_{2} \mathrm{PO}_{4}, 119 \mathrm{~mm}-\mathrm{NaCl}, 5 \mathrm{~mm}-\mathrm{KCl}$ and $2 \mathrm{~mm}-\mathrm{MgCl}_{2}$ ( $\mathrm{pH}$ 7.0). Cellular debris was removed from the suspension by filtration through cheese cloth and the spermatozoa were collected by centrifugation at $800 \mathrm{~g}$ for $5 \mathrm{~min}$. The sperm-containing pellets were washed twice in 10 volumes of the buffered salt solution to remove the exogenous carnitine and the final pellet was suspended in $0.5 \mathrm{ml}$ of the buffered salt solution. An aliquot of the suspension was removed and sperm counts were performed by conventional haemocytometer techniques. The rest of the suspension was analysed for carnitine as previously described (Casillas \& Chaipayungpan, 1979), In brief, spermatozoa were suspended in 0.5 $\mathrm{M}-\mathrm{HClO}_{4}$ and were disrupted further by sonic irradiation. Acid-insoluble material was removed by centrifugation and the acid-soluble fraction was neutralized with $\mathrm{KOH}$. The $\mathrm{KClO}_{4}$ precipitate was removed by another centrifugation and the carnitine present in the clear, neutral extracts was determined by the method described by Cederblad \& Lindstedt (1972) with modifications suggested by McGarry \& Foster (1976). The limit of sensitivity was 5 pmol and the relative deviation of 5 duplicate analyses was $2-10 \%$. In 3 experiments, the recovery of carnitine added to extracts of spermatozoa was $100 \pm 10 \%$.

\section{Experimental design}

In the first series of experiments, the proximal segments of each corpus epididymidis from 10 rabbits for each experiment were randomly assigned to a control group or to a group for culture with dihydrotestosterone. In the second series, the epididymal segments from 10 rabbits per experiment were assigned to groups for incubation with no additions (controls), dihydrotestosterone, cyproterone acetate or dihydrotestosterone plus cyproterone acetate. Another series of experiments was also performed, identical to those of Series 1 except that distal segments of the corpus epididymidis were used instead of proximal segments. Spermatozoa from each group were pooled before being analysed for carnitine. Differences between groups were compared by the $t$ test. 


\section{Materials}

Collagenase (Type II), dihydrotestosterone and carnitine acetyltransferase from pigeon muscles (98 units/mg protein) were obtained from Sigma Chemical Co., St Louis, Missouri; Medium 199 (Hanks BSS containing $1.4 \mathrm{~g} \mathrm{NaHCO}_{3} /$ ), calf serum, and penicillin-streptomycin were from Microbiological Associates, Walkersville, Maryland; L-carnitine chloride was from Supelco Inc., Bellefonte, Pennsylvania; [acetyl ${ }^{3} \mathrm{H}$ |acetyl Coenzyme A (sp. act. $1.97 \mathrm{Ci} / \mathrm{mmol}$ ) was from New England Nuclear, Boston, Massachusetts; Dowex $2 \times 8$ (200-400 mesh) was from Biorad Laboratories, Richmond, California; sodium tetrathionate was from ICN Pharmaceuticals, Plainview, New York. Cyproterone acetate was a gift from Dr John Resko, Oregon Regional Primate Research Center, Beaverton, Oregon. All other reagents were of the best grade available from commercial sources.

\section{Results}

The carnitine content of spermatozoa from tubules maintained in culture with $0.5 \mu \mathrm{g} / \mathrm{ml}$ dihydrotestosterone $\left(8.3 \pm 1.4 \mathrm{nmol} / 10^{8}\right.$ cells $)$ was significantly $(P<0.01)$ greater than in spermatozoa maintained in the absence of androgen $\left(3.1 \pm 0.3 \mathrm{nmol} / 10^{8}\right.$ cells). These results are the mean \pm s.e.m. for 15 separate experiments, 10 rabbits/experiment. The enhancement induced by dihydrotestosterone was suppressed by the simultaneous addition of cyproterone acetate to the culture medium (Table 1).

Table 1. Effect of cyproterone acetate on dihydrotestosterone (DHT)-stimulated carnitine uptake by spermatozoa

\begin{tabular}{lcccc}
\hline & & \multicolumn{2}{c}{ Culture conditions } & \\
\cline { 2 - 5 } & Control & $\begin{array}{c}\mathrm{DHT} \\
(0.5 \mu \mathrm{g} / \mathrm{ml})\end{array}$ & $\begin{array}{c}\text { Cyproterone } \\
\text { acetate } \\
(5 \mu \mathrm{g} / \mathrm{ml})\end{array}$ & $\begin{array}{c}\text { DHT }(0.5 \mu \mathrm{g} / \mathrm{ml}) \\
+ \text { cyproterone } \\
\text { acetate } \\
(5 \mu \mathrm{g} / \mathrm{ml})\end{array}$ \\
\hline $\begin{array}{c}\text { Carnitine content } \\
\left(\mathrm{nmol} / 10^{8} \text { spermatozoa) }\right.\end{array}$ & $3.0 \pm 0.6^{*}$ & $6.3 \pm 1 \cdot 1^{* \dagger}$ & $2.0 \pm 0.7$ & $3.8 \pm 0.5 \dagger$ \\
\hline
\end{tabular}

Values are \pm s.e.m. for 5 separate experiments, 10 rabbits/experiment. Sperm numbers ranged from $1.0-5.8 \times 10^{6}$ cells/analysis.

* Significantly different $(P<0.01)$.

+ Significantly different $(P<0 \cdot 05)$.

In four separate experiments, each with 10 rabbits, tubules from the distal corpus epididymidis were cultured for $24 \mathrm{~h}$ in the presence and absence of dihydrotestosterone. The carnitine content of spermatozoa from cultures containing dihydrotestosterone $(5 \cdot 0 \pm 1 \cdot 1$ $\mathrm{nmol} / 10^{8}$ cells) was the same as from control cultures $\left(4.8 \pm 0.8 \mathrm{nmol} / 10^{8}\right.$ cells $)$.

\section{Discussion}

The present results support our hypothesis that the accumulation of carnitine is one aspect of sperm maturation in the rabbit (Casillas \& Chaipayungpan, 1979). For the most part, we used the culture system described by Orgebin-Crist \& Tichenor (1973) and Orgebin-Crist \& Jahad (1978) who have demonstrated that spermatozoa maintained in culture tubules from the proximal corpus epididymidis develop the ability to fertilize ova only when androgen is added to the medium. We have shown that in this system, with the same concentration of 
dihydrotestosterone, (1) the spermatozoa accumulate carnitine, (2) the effect is blocked by the simultaneous addition of the antiandrogen, cyproterone acetate, and (3) dihydrotestosterone treatment had no effect on the carnitine levels of spermatozoa maintained in cultured tubules from the distal corpus epididymidis. Spermatozoa from this region of the rabbit epididymis in vivo are fertile (Bedford, 1966; Orgebin-Crist, 1967). The one major difference between the culture conditions used in the present study and those used by Orgebin-Crist \& Jahad (1978) was that we added $25 \mathrm{mM}$-L-carnitine to the culture medium. In preliminary experiments using media without added carnitine the spermatozoa in tubules cultured with dihydrotestosterone appeared to contain more carnitine than those in control incubations, but the differences were not significant. Carnitine was therefore added because some of the carnitine normally present in epididymal fluids leaked out of the tubules during the $24 \mathrm{~h}$ incubation period. For example, by the end of the incubation about $75 \%$ of the total carnitine was present in the medium and $25 \%$ was associated with the wet, fragile tubules in 2 experiments. The results reported here must also be interpreted cautiously in the light of results reported by Orgebin-Crist \& Jahad (1977) who found that $23 \%$ of 359 rabbits contained fertile spermatozoa in the proximal corpus epididymidis. It is possible, but not probable, that the tubules assigned to the test groups here contained more fertile spermatozoa than those assigned to the control group. Another indication that our present in-vitro studies approximate conditions found in vivo is the observation that the sperm carnitine values obtained are very similar to those found in spermatozoa removed from the corpus epididymidis of freshly killed rabbits (Casillas \& Chaipayungpan, 1979). Finally, the present report extends the results of previous investigations that have shown that epididymal carnitine levels are under androgenic control (Marquis \& Fritz, 1965b; Casillas \& Erickson, $1975 \mathrm{~b}$ ) and suggest that the uptake of carnitine by spermatozoa during epididymal transit is also controlled by androgens.

This work was supported by grants from the National Institutes of Health (HD 10664, RR 08136).

\section{References}

Bedford, J.M. (1966) Development of the fertilizing ability of spermatozoa in the epididymis of the rabbit. J. exp. Zool. 163, 319-330.

Brooks, D.E. (1980) Carnitine in the male reproductive tract and its relation to the metabolism of the epididymis and spermatozoa. In Carnitine Biosynthesis, Metabolism and Functions, pp. 219-235. Eds R. A. Frenkel \& J. D. McGarry. Academic Press, New York.

Brooks, D.E., Hamilton, D.W. \& Mallek, A.H. (1974) Carnitine and glycerylphosphorylcholine in the reproductive tract of the male rate. $J$. Reprod. Fert. 36, 141-160.

Carter, A.L., Stratman, F.W., Hutson, S.M. \& Lardy, H.A. (1980) The role of carnitine and its esters in sperm metabolism. In Carnitine Biosynthesis, Metabolism and Functions, pp. 251-263. Eds R. A. Frenkel \& J. D. McGarry. Academic Press, New York.

Casitlas, E.R. (1972) The distribution of carnitine in male reproductive tissues and its effect on palmitate oxidation by spermatozoal particles. Biochim. Biophys. Acta 280, 545-551.

Casillas, E.R. (1973) Accumulation of carnitine by bovine spermatozoa during maturation in the epididymis. J. biol. Chem. 248, 8227-8232.
Casillas, E.R. \& Chaipayungpan, S. (1979) The distribution of carnitine and acetylcarnitine in the rabbit epididymis and the carnitine content of rabbit spermatozoa during maturation. J. Reprod. Fert. 56, $439-444$.

Casillas, E.R. \& Erickson, B.J. (1975a) The role of carnitine in spermatozoa metabolism: substrateinduced elevations in the acetylation state of carnitine and coenzyme-A in bovine and monkey spermatozoa. Biol. Reprod. 12, 275-283.

Casillas, E.R. \& Erickson, B.J. (1975b) Studies on carnitine synthesis in the rat epididymis. $J$. Reprod. Fert. 44, 287-291.

Cederblad, B. \& Lindstedt, S. (1972) A method for the determination of carnitine in the picomole range. Clin. Chim. Acta 37, 235-243.

Hinton, B.T. \& Setchell, B.P. (1980) Concentration and uptake of carnitine in the rat epididymis: a micropuncture study. In Carnitine Biosynthesis, Metabolism and Functions, pp. 237-250. Eds R. A. Frenkel \& J. D. McGarry. Academic Press, New York.

Marquis, N.R. \& Fritz, I.B. (1965a) The distribution of carnitine, acetylcarnitine, and carnitine acetyltransferase in rat tissues. J. biol. Chem. 240, 2193-2196. 
Marquis, N.R. \& Fritz, I.B. (1965b) Effects of tes tosterone on the distribution of carnitine, acetylcarnitine, and carnitine acetyltransferase in tissues of the reproductive system of the male rat. $J$. biol. Chem. 240, 2197-2200.

McGarry, J.D. \& Foster, D.W. (1976) An improved and simplified radioisotopic assay for the determination of free and esterified carnitine. J. Lipid Res. 17, 277-280.

Orgebin-Crist, M.C. (1967) Maturation of spermatozoa in the rabbit epididymis: fertilizing ability and embryonic mortality in does inseminated with epididymal spermatozoa. Annls Biol. anim. Biochim. Biophys. 7, 373-389.

Orgebin-Crist, M.C. \& Jahad, N. (1977) Delayed cleavage of rabbit ova after fertilization by young epididymal spermatozoa. Biol. Reprod. 16, 358-362.
Orgebin-Crist, M.C. \& Jahad, N. (1978) The maturation of rabbit epididymal spermatozoa in organ culture: inhibition by antiandrogens and inhibitors of ribonucleic acid and protein synthesis. Endocrinologv 103, 46-53.

Orgebin-Crist, M.C. \& Tichenor, P.L. (1973) Effect of testosterone on sperm maturation in vitro. Nature, Lond. 245, 328-329.

Orgebin-Crist, M.C., Danzo, B.J. \& Davies, J. (1975) Endocrine control of the development and maintenance of sperm fertilizing ability in the epdidymis. In Handbook of Physiology, Section 7, Endocrinology, Vol. 5, Male Reproductive System, pp. 319-338. Eds D. W. Hamilton \& R. O. Greep. American Physiological Society, Washington, D.C. 